\title{
Jay Gatsby’s Smallness and Greatness in The Great Gatsby
}

\author{
Yongkun Wan \\ Yuxi Teachers College, Yuxi Municipality in Yunnan Province of China, 653100
}

Keywords: Jay Gatsby; The Great Gatsby; smallness and greatness

\begin{abstract}
Jay Gatsby, the core character of the American novel The Great Gatsby, is regarded as a typical representative of the young people of 1920s' America. Based on the essence of Jay Gatsby's inevitable tragedy, this paper aims to make an investigation into his dual personalities and the close relationship between Jay Gatsby and F. Scott Fitzgerald.
\end{abstract}

\section{Introduction}

F. Scott Fitzgerald (1896-1940), a famous American modern writer and the outstanding spokesman or singer of the Roaring Nineteen Twenties (also called "the Jazz Age" in America), accomplished and published his masterpiece The Great Gatsby in 1925[1]. The whole story of The Great Gatsby is very plain and brief, but its inner meaning is actually rather profound and complex. Jay Gatsby (1890-1922), the leading hero in The Great Gatsby, is a tragic character with dual personalities of both smallness and greatness [2].

\section{Jay Gatsby's Smallness}

Jay Gatsby, born James Gatz into a poor farmer's family in North Dakota of America, is the title character and protagonist of The Great Gatsby [3]. Following his spirit godfather-the millionaire Dan Cody, Jay Gatsby genuinely believed that money could buy everything in the world and innocently thought that his wealth could achieve the single goal of winning his lover Daisy Fay back, so he came East from the Midwest and devoted his whole life to pursuing all of his dreams of fortune, status and love.

By taking part in organized illegal transactions, Jay Gatsby earned a large sum of fortune and then became a wealthy but mysterious New Yorker. Although being rich, comfortable and lavish in materials, he was lonely, unhappy and empty in his own heart. Jay Gatsby's naivety, shallowness, vanity (or vulgarism), passion, blindness, parentage (or class) and experience made him apt to both lack the insight of understanding the world around him or even himself and impart something unworthy of himself with a sort of idealized perfection. Therefore, it is no wonder that Jay Gatsby held that Daisy Fay was his unique life desire and happiness source because she was seemingly his very "golden girl" or even holy goddess. As a matter of fact, superficially charming, graceful and young Daisy Fay was always a parasite of 1920s' American society who enjoyed luxurious lifestyle and security sense that her marriage or love affairs brought with.

Near the end of this novel, this extremely selfish Daisy Fay thoroughly abandoned Jay Gatsby and retreated back to her husband Tom Buchanan. After the ruthless society or the harsh reality together with the cold-blooded Buchanans finally destroyed Jay Gatsby's dreams, he had to die for the way out. Thus, desperate Jay Gatsby actively took the responsibility for killing Myrtle Wilson on his own and then was shot death in the swimming-pool by the avenger George Wilson. On Jay Gatsby's small funeral presided by Nick Carraway, the bleak spectacle of almost nobody's coming completely revealed his death's misery, irrelevance and pointlessness.

\section{Jay Gatsby's Greatness}

The writer F. Scott Fitzgerald employed the word "great" to qualify Jay Gatsby, which certainly had his deep connotations. Though Jay Gatsby was unable to surpass his smallness that his origins 
and past had given, he largely differed himself from all of his peers[4], which consist of his greatness. Jay Gatsby has the rare dignity, conscience and innocence of the ignorant people of that time [5].

Jay Gatsby staked almost everything, including his own life and soul, on his dreams (or ideals) or even fanciness. He dreamed that he was able to acquire vast fortune, to step into the higher social group, to possess Daisy Fay's heart and hence to pursue happiness [6]. Indeed, Jay Gatsby was a clinging and wild dream-seeker on a dangerous road doomed to ruin. Since childhood, Jay Gatsby had already made his brilliant plans for self-perfection. Owing to the unusual power to transform his partial ideals into reality, his dream of money came true. Even if his great wealth was derived from illegal means, Jay Gatsby still kept his great ambition, romantic affection, good heart, sincere nature, moral responsibility, precious self-examination, and loyal love. Consequently, he didn't forget his poor parents, but generously bought a house for them to live in; he, a typical American-dream seeker, though being much too rich, longed to acquire spiritual fulfillment more than material success; Moreover, he was always true to his beloved one (the material girl in reality) — Daisy Fray and eventually sacrificed his own life by covering the accident duty for her. On the contrary, the American modern people represented by Tom Buchanan, Daisy Fray, Jordan Bakers, Myrtle Wilson and so on should be really condemned for their spiritual wilderness, immorality, vanity, carelessness, emptiness and cruelty. Thereby, in the eighth chapter of The Great Gatsby, Nick Carraway shouted at Jay Gatsby across the lawn, "They're a rotten crowd! You're worth the whole damn bunch put together [7].”

We, today's readers and later generations, can't help sympathizing to Jay Gatsby for his tortuous life and tragic life, but at the same time admiring him for his persevering dream-pursuing. After all, it is these dream-seekers who have made greater contributions to our society's congress [8].

\section{Jay Gatsby and f. Scott Fitzgerald}

F. Scott Fitzgerald is the author of The Great Gatsby, and Jay Gatsby is the protagonist of this novel. In fact, from F. Scott Fitzgerald's personal life and literary career, it is no doubt that the image of Jay Gatsby may be considered as the personification of F. Scott Fitzgerald. They have surprisingly similar social and ideological background, unforgettable and unhappy youths, the eagerness of earning money, the means of gaining their "golden girl", and even tragic endings [9].

Both F. Scott Fitzgerald and Jay Gatsby came from the Midwest, suffered from poverty and discrimination as being youths, tasted most bitterness of life, so they were much too eager to snatch large fortune and use money to win their sweetheart's love [10]. Just like Jay Gatsby, F. Scott Fitzgerald also realized his dream of becoming rich, and in the meantime lived unhappily. Furthermore, they both received their dear girls' betrayal, tragic fates, and early death. Of course, the obvious difference between them lies in that F. Scott Fitzgerald succeeded in marrying his Venus - Zelda Sayre. However, throughout his life, F. Scott Fitzgerald's greatest happiness and deepest sorrow were just caused by his expensive wife [11].

\section{Conclusion}

In American literature, inheritance, disillusion and transcendence of the idealized and materialized American Dream is an often-written theme, which The Great Gatsby vividly reflects. Jay Gatsby's whole life started from and ended in his dreams, which made him rise vigorously, acquire money success, and fall into destruction. Both F. Scott Fitzgerald and Jay Gatsby became the victims of the era and the society of modern America. From Jay Gatsby's blindness and faults, we can easily find his smallness, but his indelible impression on us mostly results from his greatness - those peculiar excellent attributes. Though F. Scott Fitzgerald and Jay Gatsby's dreams were already over, our ones will go on and on forever. 


\section{References}

[1] W.R. Wu: History and Anthology of American Literature (Foreign Language Teaching and Research Press, China 2001), p.1-529.

[2] C.Y. Huang: The Pursuit and Loss of American Dream (In Chinese), Journal of Yulin Teachers College (Philosophy \& Social Science). 25(2004) No.1, p.45-48.

[3] M.J. Bruccoli: New Essays on The Great Gatsby (Peking University Press, China 2007), p.1-132.

[4] B.X. Zhang and J. Long: An Appreciation of English and American Classical Novels (Wuhan University Press, China 2005), p.1-356.

[5] X.C. Yang and X.C. Huang: Symbolism in The Great Gatsby, Journal of Louzhou Petrochemical College of Technology. 7(2007) No.3, p.75-77.

[6] S.J. Liu and H.S. Pan: On the Trilogy of Dreams in The Great Gatsby (In Chinese), Journal of Beijing University of Chemical Technology. 54 (2006) No.2, p.36-39.

[7] J.T. Li: On Gatsby's Double Chracters (In Chinese), Journal of liuzhou Teachers College.19 (2004) No.2, p.31-33.

[8] F.S. Fitzgerald: The Great Gatsby (Qingdao Press, China 2003), p.1-209.

[9] C.T. Li and Z.S. Li: An Learning Guide to American Literature (Tsinghua University Press, China 2001), p.1-251.

[10]F.Y. Zhang: Jay Gatsby's Greatness (In Chinese), Yantai Teachers University Journal (Philosophy and Social Sciences Edition). 18(2001) No.3, p.56-59.

[11]S.X. Sun and Y.H. Xie: Gatsby in the Eye of Fitzgerald, Journal of North China Institute of Aerospace Engineering. 17(2007) No.4, p.47-50. 